\title{
The Death Anxiety Level of Nurses During The COVID-19 Pandemic And Its Effect On The Fear Level Of Their Children Aged 6-10 Years
}

\author{
Deniz Yiğit $^{1}$ and AYFER ACIKGOZ1 \\ ${ }^{1}$ Eskisehir Osmangazi University
}

March 30, 2021

\begin{abstract}
Introduction: Nurses provide long-term care to patients diagnosed or suspected of COVID-19 during the epidemic. This situation may cause nurses to experience more fear and death anxiety and increase the fear levels of their children. This study was conducted to determine the effect of death anxiety levels of nurses on the fear level of their children during the COVID-19 pandemic. Methods: This descriptive and cross-sectional study was carried out online with 362 nurses. Data were collected using an introductory information form, the Death Anxiety Scale, and the Children's Fear Scale. Results: It was found that the death anxiety levels of nurses and fear levels of their children were high. It was determined that the children of nurses who had high death anxiety had higher fear levels. Conclusions: The findings emphasize the importance of screening nurses' death anxiety and children's fear levels during the pandemic period and providing psychological support when necessary. Keywords: COVID-19, Pandemic, Nurse, Child.
\end{abstract}

\section{Hosted file}

Main Text.pdf available at https://authorea.com/users/404869/articles/515969-the-deathanxiety-level-of-nurses-during-the-covid-19-pandemic-and-its-effect-on-the-fear-levelof-their-children-aged-6-10-years

\section{Hosted file}

Tables.pdf available at https://authorea.com/users/404869/articles/515969-the-death-anxietylevel-of-nurses-during-the-covid-19-pandemic-and-its-effect-on-the-fear-level-of-theirchildren-aged-6-10-years

\section{Hosted file}

STROBE_checklist_cross-sectional.pdf available at https://authorea.com/users/404869/articles/ 515969-the-death-anxiety-level-of-nurses-during-the-covid-19-pandemic-and-its-effecton-the-fear-level-of-their-children-aged-6-10-years 